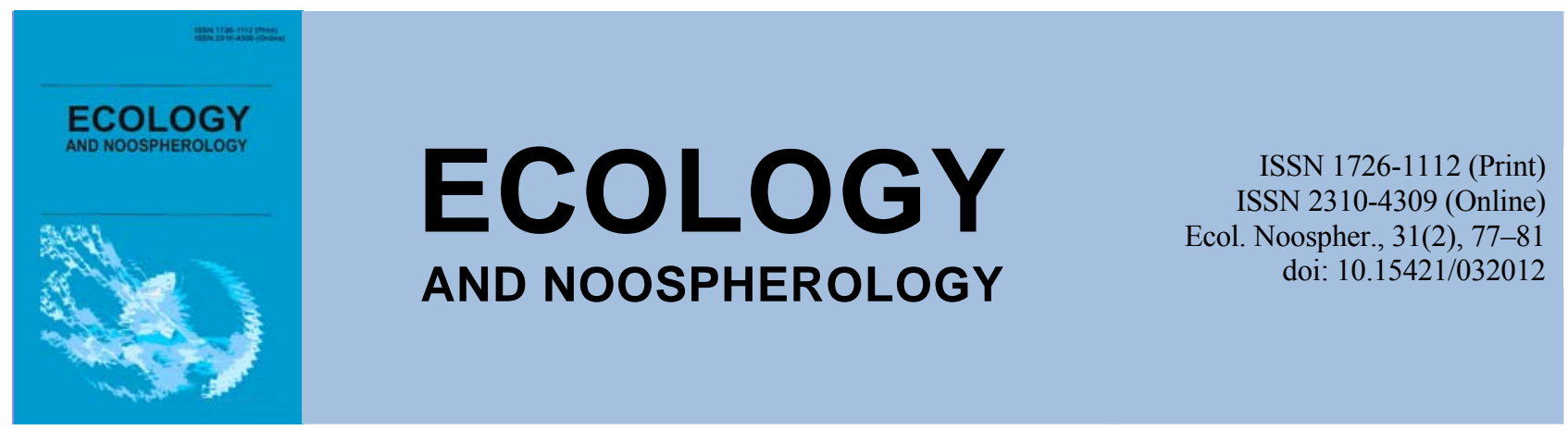

\title{
Variability at winter wheat varieties first generation which obtained mutagen action
}

\author{
M. M. Nazarenko*, T. Y. Lykholat** \\ * Dnipro State Agrarian and Economics University, Dnipro, Ukraine \\ **Oles Honchar Dnipro National University, Dnipro, Ukraine
}

Article info

Received 10.11.2020

Received in revised form 18.11.2020

Accepted 28.11.2020

Dnipro State Agrarian and Economic University,

st. Serhiy Yefremov 25 a,

Dnipro, 49600, Ukraine.

Tel.: +38-095-848-53-86

E-mail:nik_nazarenko@ukr.net

Oles Honchar Dnipro

National University,

Gagarin Ave., 72, Dnipro,

49010, Ukraine.
Nazarenko, M. M., Lykholat, T. Y. (2020). Variability at winter wheat varieties first generation which obtained mutagen action. Ecology and Noospherology, 31(2), 77-81. doi:10.15421/032012

The purpose of our investigation was to identify the features of the depressive effects of the aftereffect of different doses of gamma-rays on winter wheat varieties of local breeding in terms of germination, survival, morphometry, yield. The parameters of germination and survival, the passage of the main phases of ontogenesis in winter wheat plants of French varieties (Flamenko and Ghayta) at the first generation were studied. The influence of mutagenic depression on parameters of yield structure (morphometry of mature plants) was established and the level of their variability was estimated too. In 2019-2020, experiments were conducted in the research fields of the research center of the Dnieper State Agrarian and Economic University. The experiments used seeds of Flamenko and Ghayta varieties, irradiated with gamma rays in doses of 100, 150, 200, 250, $300 \mathrm{~Gy}$. Control was dry seeds. The variety Ghayta can be classified as resistant to gamma-rays, the variety Flamenko corresponded to high-sensitive. Parameter of germination and survival were directly correlated with increasing dose, with a dose of $200 \mathrm{~Gy}$ already semi-lethal, a dose of $250 \mathrm{~Gy}$ for variety Flamenko was sublethal, 300 Gy doze full-lethal, for the variety Ghayta sublethal was 300 Gy dose by which almost no plant material was obtained. Such parameters as plant height, weight of grains from the main spike and weight of thousand grains, weight of grains from the plant, partially number of grain from the main spike reliably reproduce the mutagenic depression. Depression of the plants is affected by the genotype of the variety more than the dose of mutagen; the plant height parameter clearly demonstrates mutagenic depression. According to the results of factor and discriminant analysis as indicators affected by genotype-mutagenic interaction should be used germination and survival, pollen sterility, plant height, grain weight per spike, weight of thousand grains weight of grains from the plant. Doses of 100-200 Gy are optimal for further use to obtain mutations; it is possible to use a dose of 250 Gy for the variety Ghayta.

Keywords: winter wheat; gamma-rays; depression; mutagenesis

\section{Мінливість у першому поколінні сортів пшениці озимої, що отримали мутагенну дію}

\author{
М. М. Назаренко*, Т. Ю. Лихолат** \\ * Дніпровський державний аграрно-економічний університет, Дніпро, Украӥна \\ **Дніпровський начіональний університет імені Олеся Гончара, Дніпро, Украӥна
}

Метою наших досліджень було виявити особливості депресивних наслідків післядії різних доз гамма-променів у сортів пшениці озимої французької селекції за показниками схожості, виживання, морфометрії, урожайності. Досліджено показники схожості та виживання, проходження основних фаз онтогенезу у рослин пшениці озимої сортів французької селекції (Flamenko та Ghayta) у першому поколінні. Установлено вплив мутагенної депресії на показники структури врожайності (морфометрію стиглих рослин) та рівень їх мінливості. У 2019-2020 pр. досліди проводилися на дослідних полях науково-дослідного центру Дніпровського державного аграрно-економічного університету. $\mathrm{y}$ дослідах використовувалося насіння сортів Flamenko та Ghayta, опромінене гамма-променями в дозах 100, 150, 200, 250,300 Гр. Контроль - сухе насіння. Сорт Ghayta можна віднести до стійких до дії гамма-променів, copт Flamenko - до високосенсетивних. Показники схожості та виживання прямо корелювали зі зростанням дози, причому доза 200 Гр. уже була напівлетальною, доза 250 Гр. для сорту Flamenko - сублетальною, доза 300 Гр. - цілком летальною, для сорту Ghayta 
сублетальною була доза 300 Гр., при якій майже не отримано рослинного матеріалу. Надійно відтворюють картину мутагенної депресії такі показники, як висота рослин, вага зерна з головного колосу та маса тисячі зерен, вага зерна 3 рослини, частково кількість зерна з головного колосу. На депресію рослин генотип сорту впливає більше, ніж доза мутагену, показник висоти рослини чітко демонструє мутагенну депресію. За результатами факторного та дискримінантного аналізу як показники, на які впливає генотип-мутагенна взаємодія, варто використовувати схожість та виживання, стерильність пилку, висоту рослин, вагу зерна з колосу, вагу зерна з рослини, масу тисячі зерен. Оптимальними, 3 огляду на подальше використання для отримання мутацій, є дози 100-200 Гр., можливе використання дози 250 Гр. для сорту Ghayta.

Ключові слова: озима пшениця; експериментальний мутагенез; депресія

\section{Вступ}

Як відомо, вплив гамма-променів на ріст та розвиток рослин зазвичай негативний та виражається у пригніченні нормальних процесів життєдіяльності, сповільненні темпів розвитку, більш пізньому настанні фаз розвитку порівняно 3 контролем (іноді до 7-10 днів за окремими фазами), зниженні схожості, виживання рослин, фертильності, прояву різних морфозів. Можлива навіть наявність невеликої кількості домінантних мутацій, але у пшениці озимої через складний геном та багатократне дублювання генетичного контролю окремих ознак частота таких мутацій незначна (або вони зовсім відсутні). Навіть незначна однократна дія мутагенними чинниками на насіння суттєво коригує продуктивність та життєздатність рослинного організму (Asif, 2020; Shu et al., 2013; SpencerLopes et al., 2018).

С досить значна кількість показників, за якими можна визначити ï ступінь, але найбільш широко вживаними $\epsilon$ схожість та виживання (особливо для озимих культур), стерильність - фертильність пилку, вага 10-денних проростків, показники структури врожайності, загальна біологічна та господарська продуктивність рослин. Ці параметри частково дублюються, а окремі показники залежно від суб'єкта мутагенної дії та особливостей росту, варіативності ознаки не є надійними для повної оцінки (Çelik et al., 2018; Hallajian, 2016).

Ступінь мутагенної депресії безпосередньо залежить, по-перше, від суб'єкта дії та його фізіологічного стану. Так, при використанні як суб'єкта сухого насіння ушкоджувальна дія найнижча, для замоченого, пророслого насіння, пилку - більш висока. На це треба зважати, обираючи дозу опромінення. По-друге, від природи мутагену - гамма-радіація, як i більшість фізичних чинників, за своїми наслідками належить до мутагенних факторів 3 високим ступенем мутагенної депресії (Hiroyasu, 2018; Kolakar et al., 2018; Nazarenko et al., 2018). $\mathrm{y}$ наших дослідженнях гамма-промені завжди призводили до найгірших наслідків за всіма показниками (Nazarenko et al., 2019; Nazarenko, 2015).

Депресія в $\mathrm{M}_{1}$ визначає кількість отриманого матеріалу для вивчення змін у наступних поколіннях, ідентифікує дію мутагену, пов'язана 3 частотою та спектром мутацій у наступних поколіннях та дає можливість добору домінантних мутацій (Hiroyasu, 2018; Shah et al., 2018).

Вивчення впливу мутагенних чинників в $\mathrm{M}_{1} \epsilon$ надзвичайно необхідним. По-перше, для ідентифікації факту мутагенної дії, по-друге, для класифікації доз, по-третє, саме в першому поколінні закладаються основні спрямування для мутаційних процесів, які будуть проявлятися в наступних поколіннях. Тобто частоту та спектр мутацій в наступних поколіннях можна прогнозувати за досліджуваними в $\mathrm{M}_{1}$ ефектами (Li et al., 2018; Nazarenko, 2015).

Існують дві методики класифікації дослідного матеріалу в $\mathrm{M}_{1}$ : перша поділяє дослідний матеріал на чотири групи - високе виживання рослин i висока фертильність, високе виживання і низька фертильність, погане виживання і низька стерильність, погане виживання і висока стерильність (Shu et al., 2013; Spencer-Lopes et al., 2018); друга, яка використовувалась для визначення ефективності мутагенних чинників в індукуванні макро- та мікромутацій, - на три типи за стерильністю та розміром пилку: тип 1 (виявляє тільки стерильність пилку), тип 2 (варіативність тільки за розміром пилку), тип 3 (проявляє як стерильність пилку, так і варіативність його розмірів) (Saif-u-Malook et al, 2015). У наших дослідах матеріал класифіковано за виживанням за дозами (Nazarenko, 2015).

Мета дослідження - виявити особливості депресії післядії різних доз гамма-променів у сортів пшениці озимої французької селекції за показниками схожості, виживання, морфометрії, урожайності.

\section{Матеріали та методи досліджень}

У 2019-2020 рр. досліди проводилися на дослідних полях науково-дослідного центру Дніпровського державного аграрно-економічного університету. У дослідах використовувалося насіння французьких сортів Flamenko та Ghayta, опромінені гамма-променями у дозах 100, 150, 200, 250, 300 Гр. Контроль - сухе насіння. Дози гаммапроменів загальновживані (Shah et al., 2018).

Опромінення сухого насіння здійснювали на гаммаустановці центра 3 ядерних досліджень та тренувань відділу експериментального мутагенезу ФАО-МАГАТЕ (Австрія, Сейберсдорф) гамма-променями радіоактивного ізотопу Со60, потужність установки 0,048 Гр./c. Насіння отримано від лабораторії екофізіології та біорізноманіття злаків (Клермон-Ферран, Франція) IHPA (Інститут національних досліджень в агрономії, Франція).

Перше покоління $\mathrm{M}_{1}$ сортів, що отримали мутагенну дію, висіяли вручну на 10-рядкових ділянках 1,5 м довжиною, у кожному варіанті 1000 зерен на ділянку. Контролем було насіння сортів, висіяне через кожні 10 рядків.

Протягом періоду вегетації 2019-2020 років були проведені обліки з виживання рослин і облік змінених рослин, також у $\mathrm{M}_{1}$ вивчався вплив мутагенів на висоту рослин та елементи структури врожаю (дібрано 50 рослин на структурний аналіз (Asif, 2020). У варіантах з високими дозами та концентраціями мутагенів добирали матеріал за наявністю. У $\mathrm{M}_{1}$ здійснювали облік польової схожості та виживання рослин. Польову схожість визначали через три тижні після посіву, коли виключалась імовірність появи додаткових сходів із насіння із сильним гальмуванням проростання, методом суцільного підрахунку рослин у варіанті. Виживання рослин у $\mathrm{M}_{1}$ визначали у відсотках кількості зібраних рослин від кількості рослин, що були посіяні. Такими, що вижили, вважали рослини, що дали хоча б один колос.

Стерильність пилку визначали фарбуванням ацетокарміном та спостереженням його інтенсивності у світловий мікроскоп. Усього проглядали не менше 25 препаратів.

Статистичну обробку отриманих результатів проводили за методом дисперсійного аналізу, достовірність різниці середніх оцінювали за критерієм Стьюдента. Використовували стандартний пакет програми Statistic 8.0.

\section{Результати та їх обговорення}

Параметри онтогенезу рослин пшениці озимої у першому поколінні наведені в табл. 1. При дії гаммапроменів також спостерігалися затримки в розвитку 
Таблиця 1

Схожість та виживання $\mathrm{M}_{1}$ рослин

\begin{tabular}{ccccc}
\hline \multirow{2}{*}{ Варіант } & \multicolumn{2}{c}{ Схожість } & \multicolumn{2}{c}{ При відновленні вегетації } \\
\cline { 2 - 5 } & шт. & $\%$ & шт. & $97,1 \pm 1,2$ \\
Flamenko, контроль & $976 \pm 12$ & $97,6 \pm 1,2$ & $971 \pm 12$ & $75,7 \pm 1,5$ \\
Flamenko, 100 Гр. & $810 \pm 14^{*}$ & $81,0 \pm 1,4$ & $757 \pm 15^{*}$ & $70,1 \pm 1,6$ \\
Flamenko, 150 Гр. & $754 \pm 14^{*}$ & $75,4 \pm 1,4$ & $701 \pm 16^{*}$ & $34,1 \pm 1,7$ \\
Flamenko, 200 Гр. & $420 \pm 20^{*}$ & $42,0 \pm 2,0$ & $341 \pm 17^{*}$ & $2,3 \pm 0,8$ \\
Flamenko, 250 Гр. & $81 \pm 11^{*}$ & $8,1 \pm 1,1$ & $23 \pm 8^{*}$ & 0 \\
Flamenko, 300 Гр. & $26 \pm 4$ & $2,6 \pm 0,4$ & $980 \pm 12$ & $98,0 \pm 1,2$ \\
Ghayta, контроль & $982 \pm 14$ & $98,2 \pm 1,4$ & $832 \pm 14^{*}$ & $83,2 \pm 1,4$ \\
Ghayta, 100 Гр. & $862 \pm 15^{*}$ & $86,2 \pm 1,5$ & $768 \pm 16^{*}$ & $76,8 \pm 1,6$ \\
Ghayta, 150 Гр. & $802 \pm 17^{*}$ & $80,2 \pm 1,7$ & $513 \pm 15^{*}$ & $51,3 \pm 1,5$ \\
Ghayta, 200 Гр. & $611 \pm 14^{*}$ & $61,1 \pm 1,4$ & $131 \pm 11^{*}$ & $13,1 \pm 1,1$ \\
Ghayta, 250 Гр. & $241 \pm 20^{*}$ & $24,1 \pm 2,0$ & $57 \pm 8^{*}$ & $5,7 \pm 0,8$ \\
Ghayta, 300 Гр. & $116 \pm 8^{*}$ & $11,6 \pm 0,8$ & & \\
\hline
\end{tabular}

* Різниця статистично достовірна при $\mathrm{P}_{0.05}$.

рослин: у сортів Flamenko та Ghayta фаза колосіння настала на 4 дні пізніше, повна стиглість - на 4-5 днів при дозах вище 100 Гр. При дозах вище 200 Гр. - на 6 днів. Фаза повної стиглості відповідно майже на тиждень та декаду. Багато рослин було недорозвинених, з численними морфозами, особливо при дозах вище 200 Гр. У контролі вихідний матеріал суттєво не розрізнявся за схожістю. При дії окремих доз знаходимо, що у випадку цих генотипів copт Ghayta можна віднести до стійких до дії гаммапроменів, сорт Flamenko до високосенсетивних. Так, дія доволі помірної дози 200 Гр. була напівлетальною за виживанням. Доза 250 Гр. виявилась для першого сорту сублетальною.

При визначенні генотип-мутагенної взаємодії знаходимо, що сорт Ghayta був менш чутливим до дії гамма-променів у діапазоні 100-250 Гр., але при дії 300 Гр. він також продемонстрував майже повну загибель (доза була сублетальною). Для другого сорту летальною виявилась доза 300 Гр. - при майже нульовій схожості. Щодо виживання, то для обох генотипів спостерігалась значна віддалена загибель унаслідок зимових умов, що була статистично достовірною, але в сорта Flamenko вона більш суттєва.

Таким чином, можна провести таку класифікацію доз для генотипів французької селекції: дози 100-200 Гр. оптимальні, доза 250 Гр. - сублетальна та напівлетальна, доза 300 Гр. - летальна та сублетальна. Це досить чітко відрізняється від загальновживаної класифікації, де дози $100-150$ Гр. є помірними, 200-250 Гр. високими та 300 Гр. - сублетальними для першого сорту, сорт Ghayta достатньо стійкій за параметрами експериментального мутагенезу.

Крім показників схожості та виживання ключовою ознакою розвитку рослин $є$ проходження відповідних фаз (про що буде сказано далі) та здатність дати плодючих нащадків. 3 цього приводу оптимальним $€$ контроль за життєздатністю пилкових зерен, що проводиться доволі простим методом прокрашування пилкових зерен та обліком наявності та кількості фертильних зерен при мікроскопуванні зразків.

У показника «фертильність пилку» (наведений у табл. 2) кореляція між дозою гамма-променів та спадом фертильності на рівні - 0,92, тобто при підвищенні дози стерильність лінійно зростала.

У цьому випадку фертильність поступово знижувалася при зростанні доз гамма-променів дози 200 Гр., після якої відбулося стрімке падіння - тобто 3 огляду на цей тип моніторингу критичним $\epsilon$ використання діапазону за 200 Гр., використання доз менших та рівних 200 Гр. призводить до помірної втрати фертильності.

У контролі обидва сорти продемонстрували високий рівень фертильності, при дозі 100 Гр. фертильність значущо знизилась, але поступово. Дія дози 150 Гр. знов призвела до значущого зростання стерильності, що вже становила лише 80 відсотків від норми, доза 200 Гр. призвела до формування фертильності на рівні 60-70 \% від загальної кількості пилкових зерен, при цьому сорти вже значущо розрізнялись. В усіх випадках сорт Ghayta демонстрував вищу стійкість до гамма-променів, ніж сорт Flamenko, як у випадку схожості та виживання. Для останнього доза 300 Гр. викликала повну стерильність.

Однією 3 вагомих проблем, що істотно знижують кількість матеріалу для добору на ранніх ланках процесу генетичного поліпшення в експериментальному мутагенезі, є негативний вплив гамма-променів, особливо у високих дозах, на окремі ключові елементи структури врожайності.

Структура врожайності досліджена за 9 стандартними показниками, наведеними в табл. 3. Показники «загальна кущистість», «продуктивна кущистість», «довжина головного колосу», «кількість колосків 3 колосу», як правило, не знижувались із статистичною достовірністю при зміні дози. Звичайно, мутагенна депресія вплинула й на них, та значення будь-якого 3 цих показників при дії критичної або напівлетальної дози значно відрізнялося від контролю. При цьому потрібно орієнтуватися на ознаки,

\section{Таблищя 2}

Рівень фертильності у $\mathrm{M}_{1}$ рослин

\begin{tabular}{ccc}
\hline Варіант & Flamenko & Ghayta \\
\hline Контроль & 99,1 & 99,2 \\
Гамма-промені, 100 Гр. & $84,3^{*}$ & $88,1^{*}$ \\
Гамма-промені, 150 Гр. & $77,4^{*}$ & $80,6^{*}$ \\
Гамма-промені, 200 Гр. & $59,7^{*}$ & $69,0^{*}$ \\
Гамма-промені, 250 Гр. & $10,1^{*}$ & $16,1^{*}$ \\
Гамма-промені, 300 Гр. & - & $1,4^{*}$ \\
\hline
\end{tabular}

* Різниця статистично достовірна 3 попереднім варіантом при $\mathrm{P}_{0,05}$. 
Таблиця 3

Основні показники структури врожайності $\mathrm{M}_{1}$ сортів

\begin{tabular}{cccccccccc}
\hline Варіант & \multirow{2}{*}{ В } & ЗК & ПК & ДГК & КК & ЗГК & ВЗГК & \multirow{2}{*}{ ВЗР } & МТЗ \\
\hline Flamenko, контроль & 78,6 & 3,7 & 3,4 & 8,1 & 16,8 & 31,0 & 1,11 & 3,7 & 35,4 \\
Flamenko, 100 Гр. & $72,2^{*}$ & 3,5 & 3,2 & 7,7 & 16,3 & 30,0 & 1,01 & 3,3 & $32,5^{*}$ \\
Flamenko, 150 Гр. & $67,1^{*}$ & 3,4 & 3,2 & 7,3 & 15,7 & 27,0 & $0,91^{*}$ & $2,8^{*}$ & $30,6^{*}$ \\
Flamenko, 200 Гр. & $51,0^{*}$ & 2,9 & 2,8 & 6,7 & 14,9 & $20,0^{*}$ & $0,51^{*}$ & $1,1^{*}$ & $24,1^{*}$ \\
Flamenko, 250 Гр. & $37,2^{*}$ & $1,0^{*}$ & $1,0^{*}$ & $4,3^{*}$ & $8,9^{*}$ & $2,0^{*}$ & $0,15^{*}$ & $0,1^{*}$ & $14,0^{*}$ \\
Ghayta, контроль & 77,5 & 3,9 & 3,7 & 10,4 & 21,6 & 47,0 & 2,34 & 5,6 & 52,7 \\
Ghayta, 100 Гр. & $71,7^{*}$ & 3,6 & 3,4 & 9,7 & 20,9 & 45,0 & $2,12^{*}$ & $3,9^{*}$ & $48,1^{*}$ \\
Ghayta, 150 Гр. & $65,2^{*}$ & 3,5 & 2,9 & 9,3 & 20,5 & $43,0^{*}$ & $1,97^{*}$ & 3,6 & $43,0^{*}$ \\
Ghayta, 200 Гр. & 53,3 & 3,0 & 2,4 & 8,8 & 19,9 & $34,0^{*}$ & $1,21^{*}$ & $1,5^{*}$ & $35,2^{*}$ \\
Ghayta, 250 Гр. & 36,3 & $1,9^{*}$ & $1,4^{*}$ & $7,3^{*}$ & $19,0^{*}$ & $27,0^{*}$ & $0,49^{*}$ & $0,9^{*}$ & $27,1^{*}$ \\
Ghayta, 300 Гр. & 28,9 & 1,4 & 1,0 & $5,4^{*}$ & $7,9^{*}$ & $2,0^{*}$ & $0,31^{*}$ & $0,4^{*}$ & $14,0^{*}$ \\
\hline
\end{tabular}

В - висота, см; ЗК - загальна кущистість; ПК - продуктивна кущистість; ДГК - довжина головного колосу, см; КК - кількість колосків, шт.; ЗГК - зерна з головного колосу, шт.; ВЗГК - вага зерна з головного колосу, г; ВЗР - вага зерна 3 рослини, г; МТЗ - маса тисячі зерен, г.

* Різниця з попереднім варіантом статистично достовірна при $\mathrm{P}_{0,05}$.

які змінюються 3 кожною зміною дози, проте й за цими ознаками дози 100 та 150 Гр., 150 та 200 Гр. здатні не відрізнятися одна від одної.

Ознака «висота рослин» при дії дози 100 Гр. знижувалась статистично значуще порівняно з контролем у обох сортів. Те саме відбувалося при дії доз 150-300 Гр. Тобто статистично достовірно знижується при дії будьякої дози. Ознака «загальна кущистість» набагато менш варіативна та змінюється при зростанні дози лише при дії 250-300 Гр. При дії гамма-променів на ознаку «продуктивна кущистість» спостерігається фактично та сама картина. Щодо ознаки «довжина колоса», то він варіативний теж лише при дії 250-300 Гр. у обох сортів. Та сама картина спостерігається у показника «кількість колосків з головного колосу».

Така морфометрична ознака, як «кількість зерна 3 головного колосу», варіює при дозах крім 200-250 Гр. зі статистичною достовірністю та $\epsilon$ досить чутливим показником мутагенної депресії лише при високих значеннях гамма-променів для сорту Flamenko. Для сорту Ghayta достатньо відтворює всі дози. Вага зерна 3 головного колосу варіює при всіх без винятку дозах та повністю відповідає за мінливістю всім параметрам для надійного моніторингу депресійного впливу гаммапроменів та ідентифікації факту мутагенної дії. Тобто фактично на одному рівні з показником «висота рослини». Вага зерна 3 рослини дещо поступається попередньому показникові та відображає мутагенну депресію при дозах 100-150 Гр. не завжди, МТЗ (маса тисячі зерен) достовірно змінюється при дії будь-якої дози мутагену в обох сортах та $є$ надійним параметром мутагенної активності на рівні показників «висота рослини» та «вага зерна з головного колосу».

Таким чином, надійно відтворюють картину мутагенної депресії такі показники, як висота рослин, вага зерна 3 головного колосу та МТЗ, вага зерна з рослини, частково кількість зерна 3 головного колосу. Стимулюючого ефекту не виявлено.

За інформативністю 3 варіювання щодо поступової зміни ознаки при зростанні дози мутагену можна виділити за дискримінантним аналізом (табл. 4) такі показники, як: висота рослини, вага зерна з головного колосу, маса тисячі зерен. Менш інформативні показники: вага зерна 3 рослини, кількість зерен з головного колосу.

За результатами двофакторного аналізу (табл. 5) доведено, що спостерігався вплив фактора «доза мутагену» на ознаки структури $\mathrm{M}_{1}$ сортів - висота рослин, вага зерна 3 колосу, вага зерна з рослини, маса тисячі зерен. Він був основним у диференціації за ступенем мутагенної депресії. За результатами аналізу за фактором «генотип сорту» він вплинув на такі показники: висота рослин, кількість зерен 3 колосу, вага зерна 3 колосу, вага зерна 3 рослини, маса тисячі зерен. Вочевидь, на це вплинули особливості сортів у формуванні врожаю та значуще більш висока врожайність другого сорту.

Отже, на депресію сорту генотип у цьому випадку впливає більше, ніж доза мутагену, показник «висота рослини» чітко демонструє мутагенну депресію. Як показники мутагенної дії варто використовувати висоту рослин, вагу зерна 3 колосу, масу тисячі зерен, вагу зерна 3 рослини, в окремих випадках - кількість зерна з головного колосу.

\section{Таблиця 4}

Результати дискримінантного аналізу

\begin{tabular}{cccc}
\hline Змінні в моделі & $\begin{array}{c}\text { Коефіцієнт Уїлкса } \\
\lambda\end{array}$ & $\begin{array}{c}\text { F-remove } \\
(4,02)\end{array}$ & p-level \\
\hline Висота, см & 0,61 & 11,93 & 0,01 \\
Загальна кущистість & 0,02 & 0,63 & 0,41 \\
Продуктивна кущистість & 0,02 & 0,61 & 0,31 \\
Довжина головного колосу, см & 0,04 & 0,67 & 0,40 \\
Кількість колосків, шт. & 0,03 & 0,64 & 0,35 \\
Зерна з головного колосу, шт. & 0,20 & 4,11 & 0,03 \\
Вага зерна з головного колосу, г & 0,31 & 5,73 & 0,01 \\
Вага зерна з рослини, г & 0,25 & 4,98 & 0,02 \\
МТЗ, г & 0,68 & 17,32 & 0,01
\end{tabular}


Таблиця 5

Результати факторного аналізу (varimax raw)

\begin{tabular}{ccc}
\hline Параметр & Генотип сорту & Доза мутагену \\
\hline Висота, см & $\mathbf{0 . 8 0 1 2 1 7}$ & $\mathbf{- 0 . 9 5 4 5 6 3}$ \\
Загальна кущистість & 0.303161 & 0.292326 \\
Продуктивна кущистість & 0.154364 & 0.100965 \\
Довжина головного колосу, см & 0.203473 & 0.108976 \\
Кількість колосків, шт. & 0.154637 & 0.143432 \\
Зерна з головного колосу, шт. & $\mathbf{0 . 7 4 0 1 2 7}$ & -0.431759 \\
Вага зерна з головного колосу, г & $\mathbf{0 . 7 8 6 5 4 9}$ & $\mathbf{- 0 . 8 2 3 4 3 4}$ \\
Вага зерна з рослини, г & $\mathbf{0 . 6 1 4 2 1 7}$ & $\mathbf{- 0 . 6 9 5 9 4 9}$ \\
МТЗ, г & $\mathbf{0 . 8 8 6 5 8 8}$ & $\mathbf{- 0 . 9 2 3 4 4 4}$ \\
Загальна дисперсія & 2.432657 & 2.876548 \\
Доля загальної дисперсії & 0.654766 & 0.734533 \\
\hline
\end{tabular}

\section{Висновки}

Вища депресія за всіма дослідженими ознаками проявилась у сорту Flamenko, що свідчить про специфічність взаємодії депресійної активності гаммапроменів 3 генотипами окремих сортів та складний характер розвитку депресивних наслідків на рівні організму. Найбільш інформативними показниками щодо мутагенної депресії у $\mathrm{M}_{1}$ поколінні рослин сортів пшениці озимої м'якої були: схожість та виживання рослин, фертильність пилку та такі показники структури врожайності, як висота рослин, вага зерна 3 головного колосу, маса тисячі зерен, вага зерна 3 рослини. Генотипи сортів французької селекції виявилися різними по відношенню до дії гамма-променів, що проявилось у більш високій чутливості у сорту Flamenko. Це показує їх кардинальні особливості при використанні як суб' єктів для мутаційної мінливості в майбутньому - оптимальним 3 огляду на подальше використання для отримання мутацій $\epsilon$ дози 100-200 Гр., але для сорту Ghayta можливе використання дози 250 Гр. У подальшому планується дослідження частоти змін у другому поколінні та перевірка ïx успадкування у третьому поколінні, визначення перспективних форм.

\section{References}

Asif, J. (2020). Effect of different pre-treatments on seed germination of Prosopis juliflora and Dalbergia sissoo: a step towards mutation breeding. Journal of forest science, $66,80-88$.

Çelik, Ö., Ekşioğlu, A. \& Akdaş, E. Y. (2018). Transcript profiling of salt tolerant tobacco mutants generated via mutation breeding. Gene Expression Patterns, 29, 59-64.
Hallajian, M. T. (2016). Mutation Breeding and Drought Stress Tolerance in Plants. Drought Stress Tolerance in Plants, 2, 359-383.

Hiroyasu, Y. (2018). Mutation breeding of ornamental plants using ion beams. Breeding Science, 68(1), 71-78.

Kolakar, S. S., Nadukeri, S., Jakkeral, S. A., Hanumanthappa, M. \& Gangaprasad, S. (2018). Role of mutation breeding in improvement of medicinal and aromatic crops: Review. Journal of Pharmacognosy and Phytochemistry, SP3, 425-429.

Li, H. J., Timothy, D. M., Mc Intoshc, R.A. \& Zhou, Y. (2019). Wheat breeding in northern China: achievements and technical advances. The Crop Journal, 7(6), 718-729.

Nazarenko, M. (2015). Negativnyie posledstviya mutagennogo vozdeystviya [Peculiarities of negative consequences of mutagen action]. Ecological Genetics, 13(4), 25-26 (in Russian).

Nazarenko, M., Beiko, V. \& Bondarenko, M. (2019). Induced mutations of winter wheat caused by gamma-rays fixed on plant height and stem structure. Agriculture and Forestry, 65(3), 75-83.

Nazarenko, M., Lykholat, Y., Grigoryuk, I., Khromykh, N. (2018). Optimal doses and concentrations of mutagens for winter wheat breeding purposes. Part I. Grain productivity. Journal of Central European Agriculture, 19(1), 194-205.

Saif-u-Malook, S. A., Qaisarani, M. K., Shabaz, H., Ahmed, M., Nawaz, M. \& Qurban, A. (2015). Mutation breeding approach to breed drought tolerant maize hybrids. International Journal of Biosciences, 6(2), 427-436.

Shah, F., Adnan, M. \& Basir, A. (2018). Global Wheat Production. Intechopen, London.

Shu, Q. Y., Forster, B. P. \& Nakagava, H. (2013). Plant mutation breeding and biotechnology. CABI publishing, Vienna.

Spencer-Lopes, M. M., Forster, B. P. \& Jankuloski, L. (2018). Manual on mutation breeding. Third edition. Food and Agriculture Organization of the United Nations, Rome. 